\title{
Short communication: Technological and genotypic comparison between Streptococcus macedonicus and Streptococcus thermophilus strains coming from the same dairy environment
}

\author{
G. Blaiotta, ${ }^{*}$ A. Sorrentino, $†$ A. Ottombrino, $†$ and M. Aponte ${ }^{* 1}$ \\ *Dipartimento Scienza degli Alimenti, Università degli Studi di Napoli Federico II, Via Università 100, 80055 Portici (NA), Italy \\ †Istituto di Scienze dell'Alimentazione, ISA-CNR, Via Roma, 64, 83100 Avellino, Italy
}

\begin{abstract}
The species Streptococcus thermophilus is widely used for the preparation of several dairy products, and its technological contribution is clear. On the other hand, although Streptococcus macedonicus was first described more than $10 \mathrm{yr}$ ago and, despite the scientific interest around this issue, the exact role of Strep. macedonicus in cheese making has yet to be clarified. In this study, 121 strains belonging to both species and isolated from the same dairy environment were genetically characterized by random amplification of polymorphic DNA (RAPD)-PCR and compared for the main biochemical features of technological interest, such as acid production, galactose utilization, citrate metabolism, exopolysaccharide production, and lipolytic, ureolytic, exocellular proteolytic, and decarboxylasic activities. Analysis by RAPD-PCR highlighted a remarkable genotypic heterogeneity among strains in both species, and, at a similarity level of $78 \%$, all the isolates and reference strains of Strep. thermophilus grouped together and were well separated from the strains of Strep. macedonicus, confirming that these 2 species are different microbial entities. Comparison between genetic and phenotypic or biotechnological data did not reveal any relationships.
\end{abstract}

Key words: Streptococcus thermophilus, Streptococcus macedonicus, random amplification of polymorphic DNA (RAPD)-PCR, Provolone del Monaco cheese

\section{Short Communication}

During a survey on the evolution of the lactic acid bacteria microbiota throughout the manufacturing and ripening process of Italian Provolone del Monaco cheese, 121 strains belonging to the species Streptococcus macedonicus and Streptococcus thermophilus were

Received June 17, 2011.

Accepted August 16, 2011.

${ }^{1}$ Corresponding author: aponte@unina.it isolated (Aponte et al., 2008). The genus Streptococcus includes pathogenic species widely distributed in humans and animals, together with "generally recognized as safe" (GRAS) species found in raw milk, dairy products, and plant materials. The species Strep. thermophilus is widely used in the preparation of several dairy products, such as fermented milks, yogurt, and cheeses. The role of Strep. thermophilus in milk fermentation is related not only to the production of lactic acid that allows a $\mathrm{pH}$ decrease of the medium, but also to several other important technological properties that must be considered when selecting strains for starter preparation. Streptococcus macedonicus possesses a food-grade and nonpathogenic status (Poyart et al., 2002). Strains of Strep. macedonicus are weak milk acidifiers and generally possess low proteolytic and citrate-catabolizing activities but moderate lipolytic activity (De Vuyst and Tsakalidou, 2008). Several strains produce exopolysaccharides (Vincent et al., 2001) or exhibit antimicrobial activity (Georgalaki et al., 2000; Zoumpopoulou et al., 2008). These physiological and technological properties make Strep. macedonicus a multi-functional candidate coculture for dairy food applications. Since its description by Tsakalidou et al. (1998), Strep. macedonicus has been detected in various cheeses (Andrighetto et al., 2002; Baruzzi et al., 2002; Callon et al., 2004; Lombardi et al., 2004; Poznanski et al., 2004; Pacini et al., 2006; Aponte et al., 2008; Georgalaki et al., 2009) and in one Mexican fermented maize beverage (Díaz-Ruiz et al., 2003). However, the exact role of Strep. macedonicus in cheese making has yet to be elucidated.

In this study, 71 strains of Strep. macedonicus and 50 strains of Strep. thermophilus from the same food ecosystem (Aponte et al., 2008) were genetically characterized and compared for the main biochemical features of technological interest (Table 1). Acid production in pasteurized cow milk after $6 \mathrm{~h}$ at $37^{\circ} \mathrm{C}(1 \% \mathrm{vol} / \mathrm{vol}$ inoculum) was evaluated according to Georgalaki et al. (2000), whereas the utilization of galactose was tested as described by Moschetti et al. (1998). Determination of lipolytic, ureolytic, and exocellular proteolytic 
Table 1. Streptococcus spp. strains isolated during manufacture and ripening of Provolone del Monaco cheese (Aponte et al., 2008)

\begin{tabular}{|c|c|c|c|c|c|c|c|c|c|}
\hline \multirow[b]{2}{*}{ Species } & \multicolumn{8}{|c|}{ Sample $^{1}$} & \multirow[b]{2}{*}{ Medium $^{2}$} \\
\hline & M & $\mathrm{C}_{0}$ & $\mathrm{C}_{\mathrm{F}}$ & $\mathrm{C}_{\mathrm{S}}$ & $\mathrm{C}_{\mathrm{B}}$ & $\mathrm{C}_{1}$ & $\mathrm{C}_{5}$ & $\mathrm{C}_{9}$ & \\
\hline Strep. thermophilus & $13(-5)^{3}$ & $\begin{array}{l}305,307,308 \\
309,310 \mathrm{pg}, \\
312,314(-6) \\
315(-7)\end{array}$ & $\begin{array}{l}57(-7) ; 68 \\
69(-8)\end{array}$ & $\begin{array}{l}75,80(-7) \\
82 \mathrm{a}, 82 \mathrm{~b}(-8)\end{array}$ & $\begin{array}{l}242,243(-7) \\
246,247(-8)\end{array}$ & & $381(-5)$ & & $\mathrm{M}_{3}$ \\
\hline Strep. thermophilus & $\begin{array}{l}26,27,30 \\
33(-5) ; 49 \\
50(-6)\end{array}$ & $\begin{array}{l}34,35,40,41 \\
43,44,46,48 \\
49,50(-6) \\
53(-7)\end{array}$ & $\begin{array}{l}83,84,85 \\
87(-7) ; 92 \\
94,95(-8)\end{array}$ & $\begin{array}{l}101,103,104 \\
105(-7)\end{array}$ & $230,232(-7)$ & $333(-6)$ & & & $\mathrm{M}_{4}$ \\
\hline Strep. macedonicus & & $310 \mathrm{pb}(-6)$ & $\begin{array}{l}56,58,59(-7) \\
65,67(-8)\end{array}$ & $\begin{array}{l}70,71,72,73 \\
74,78(-7) \\
81(-8)\end{array}$ & $\begin{array}{l}237,238,239 \\
240,241(-7) \\
245(-8)\end{array}$ & $\begin{array}{l}371(-6) ; 373 \\
374,376,377 \\
378(-7)\end{array}$ & $\begin{array}{l}380,382(-5) \\
383,384,385 \\
386,387,388 \\
389(-6) \\
390(-7)\end{array}$ & $448(-5)$ & $\mathrm{M}_{3}$ \\
\hline Strep. macedonicus & & $\begin{array}{l}42,45(-6) \\
51(-7)\end{array}$ & $\begin{array}{l}88,90,96 \\
97(-8)\end{array}$ & $\begin{array}{l}98,100(-7) \\
106,108,109 \\
111(-8)\end{array}$ & $\begin{array}{l}227,228,229 \\
231,234(-7)\end{array}$ & $\begin{array}{l}331(-6) \\
335(-7)\end{array}$ & $\begin{array}{l}392,393,394 \\
395,396,397 \\
(-5) ; 399 \\
400(-6)\end{array}$ & $\begin{array}{l}456,458,460 \\
461,462(-5) \\
464(-6)\end{array}$ & $\mathrm{M}_{4}$ \\
\hline $\begin{array}{l}\text { Strep. macedonicus } \\
\text { Strep. macedonicus }\end{array}$ & & & & & $282(-6)$ & & $414(-5)$ & & $\begin{array}{l}\text { SB } \\
\mathrm{I}\end{array}$ \\
\hline
\end{tabular}

${ }^{1}$ Samples were collected during cheesemaking of Provolone del Monaco: $\mathrm{M}=$ milk before cheesemaking: $\mathrm{C}_{0}=$ curd after cooking: $\mathrm{C}_{\mathrm{F}}=$ curd at the end of fermentation; $\mathrm{C}_{\mathrm{S}}=$ cheese after stretching; $C_{B}=$ cheese after brine; $C_{1}=$ cheese after 1 mo of ripening; $C_{5}=$ cheese after 5 mo of ripening; $C_{9}=$ cheese after 9 mo of ripening.

${ }^{2}$ Media and incubation conditions. $\mathrm{M}_{3}=\mathrm{M} 17$ agar incubated at $30^{\circ} \mathrm{C} ; \mathrm{M}_{4}=\mathrm{M} 17$ agar incubated at $44^{\circ} \mathrm{C} ; \mathrm{SB}=$ Slanetz \& Bartley agar incubated at $37^{\circ} \mathrm{C} ; \mathrm{I}=\mathrm{Isolini}$ agar $($ Isolini et al., 1990) incubated in anaerobiosis at $37^{\circ} \mathrm{C}$.

${ }^{3}$ Strains of each sample with isolation dilution in parentheses. Reference strains used in this study included Strep. thermophilus DSM20259, DSM20479, DSM 8713, and DSM20617 obtained from DSM: Deutsche Sammlung von Mikroorganismen und Zellkulturen (Braunschweig, Germany). 
activities was carried out according to Georgalaki et al. (2000), Lanyi (1987), and Franciosi et al. (2009), respectively. Screening for decarboxylase activity was performed as reported by Joosten and Northolt (1989) with ornithine, histidine, and tyrosine (Sigma, Milan, Italy) as decarboxylase substrates. Strains were screened for citrate metabolism using Simmons citrate agar (Oxoid, Basingstoke, UK). Exopolysaccharide (EPS) production was tested in ST1 medium (Gancel and Novel, 1994) supplemented with filter-sterilized solutions of different carbohydrates $(1 \% \mathrm{vol} / \mathrm{vol})$ and ruthenium red $(0.08 \mathrm{~g} / \mathrm{L})$. Glucose, galactose, lactose, saccharose, fructose, and skim milk powder were added one by one.

For genotypic characterization, DNA from pure cultures was extracted according to a procedure developed ad hoc. Briefly, cells grown in $10 \mathrm{~mL}$ of de Man, Rogosa, and Sharpe medium to the exponential phase were washed in saline-Tris-EDTA $(100 \mathrm{mM} \mathrm{NaCl}, 10 \mathrm{mM}$ Tris-HCl, $1 \mathrm{~m} M$ EDTA, $\mathrm{pH}$ 8.00), suspended in 250 $\mu \mathrm{L}$ of lysis solution $(50 \mathrm{~m} M$ Tris- $\mathrm{HCl}, 5 \mathrm{~m} M$ EDTA, $\mathrm{pH} 8.00$ ) containing $1.6 \mathrm{mg} / \mathrm{mL}$ of lysozyme, $40 \mathrm{U} / \mathrm{mL}$ of mutanolysin, and $0.4 \mathrm{mg} / \mathrm{mL}$ RNase, and incubated overnight at $37^{\circ} \mathrm{C}$. Twenty-five microliters of $25 \%$ ( $\mathrm{vol} /$ vol) SDS and $2 \mu \mathrm{L}$ of pronase $(20 \mathrm{mg} / \mathrm{mL})$ were added, and incubation was allowed to proceed at $37^{\circ} \mathrm{C}$ for $1 \mathrm{~h}$. A quantity of sodium acetate $(5 M)$ equal to the volume of the water phase was added, and, after cooling at $0^{\circ} \mathrm{C}$, DNA was precipitated by centrifugation $(14,000 \times$ $g$ for 10 min at $4^{\circ} \mathrm{C}$ ) with 0.7 volumes of isopropanol. Finally, the pellet was washed with $70 \%$ ethanol and, after drying, nucleic acids were dissolved in $50 \mu \mathrm{L}$ of rehydration buffer (Promega, Madison, WI; $55^{\circ} \mathrm{C}$ for $1 \mathrm{~h})$. Concentration of DNA of samples was estimated by Nanodrop (Thermo Scientific, Wilmington, DE). All reagents, unless otherwise noted, were from Sigma.
Random amplification of polymorphic DNA (RAPD)-PCR reactions were performed with primer XD9 (5'-GAAGTCGTCC-3'). Temperature profile was as follows: 40 cycles consisting of $94^{\circ} \mathrm{C}$ for $1 \mathrm{~min}$, $31^{\circ} \mathrm{C}$ for $1 \mathrm{~min}$, and $72^{\circ} \mathrm{C}$ for $2 \mathrm{~min}$; the final extension was continued for $7 \mathrm{~min}$ at $72^{\circ} \mathrm{C}$. The PCR products were separated by electrophoresis $(2 \mathrm{~h}$ at $130 \mathrm{~V})$ on $1.5 \%$ (wt/vol) agarose gel (Invitrogen, Cergy-Pontoise, France), and the DNA was detected by UV transillumination after staining with ethidium bromide $(0.5 \mu \mathrm{g} /$ $\mathrm{mL})$. Photopositives were analyzed using the Bionumerics software, version 5.1 (Applied Maths, Kortrijk, Belgium). The RAPD-PCR patterns were grouped by means of cluster analysis with the Pearson productmoment correlation coefficient and the unweighted pair group method using arithmetic averages (UPGMA).

Depending on the $\mathrm{pH}$ reached after $6 \mathrm{~h}$ of incubation in milk, strains were arbitrarily classified into 3 categories: good acidifiers ( $\mathrm{pH}$ values $<5.00$ ), fair acidifiers (pH values ranging between 5.00 and 6.00 ), and poor acidifiers ( $\mathrm{pH}$ values $>6.00$ ). According to this arbitrary classification, no Strep. macedonicus strain could be considered a good acidifier and just 19 strains out of 71 (about $27 \%$ ) could be reported as fair acid producers in cow milk (Figure 1). Among these 19 strains, 17 (about $24 \%$ of the entire group) exhibited extracellular proteolytic activity on skim milk (Figure 2). In other words, Strep. macedonicus was confirmed to be a moderately acidifying species (Georgalaki et al., 2000; Lombardi et al., 2004; De Vuyst and Tsakalidou, 2008), but the percentage of proteolytic strains recorded in this survey appeared to be significantly higher than that obtained by other authors (Georgalaki et al., 2000; Lombardi et al., 2004). On the other hand, Strep. thermophilus strains showed better performance in milk and just 18 out of 50 (approximately $36 \%$ ) led to weak acidifica-

\footnotetext{
Good acidifiers $(\mathrm{pH}<5.00)$

Fair acidifiers $(5.00>\mathrm{pH}<6.00)$

Poor acidifiers $(\mathrm{pH}>6.00)$
}

S. macedonicus

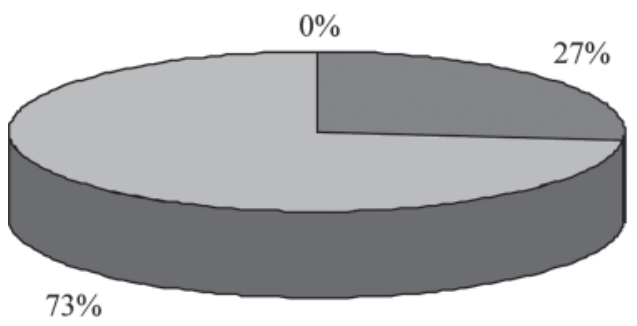

S. thermophilus

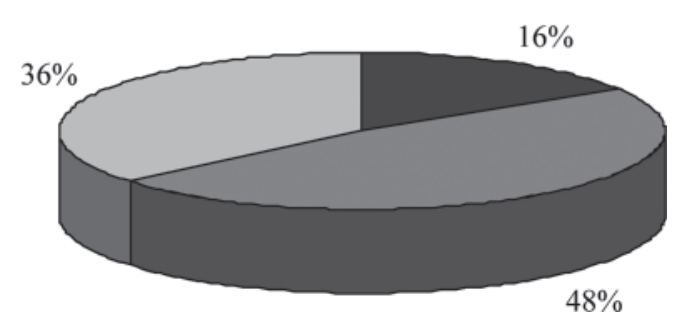

Figure 1. Acid production of Streptococcus macedonicus and Streptococcus thermophilus strains expressed as $\mathrm{pH}$ values after $6 \mathrm{~h}$ in pasteurized cow milk. 


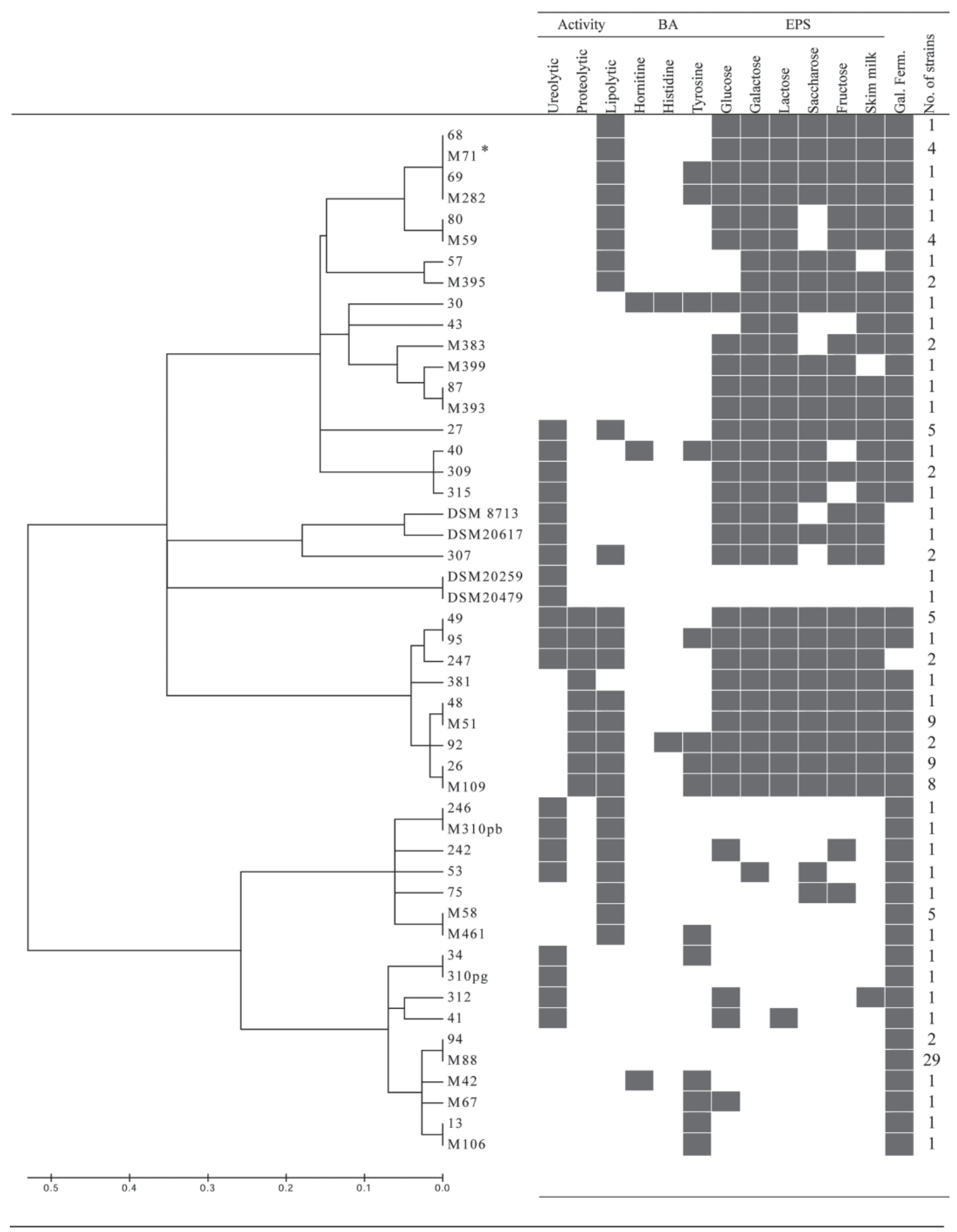

Figure 2. Cluster analysis-based dendrogram (unweighted pair group algorithm with arithmetic averages method) showing diversity of Streptococcus strains with respect to the utilization of carbon sources, enzyme activities, and exopolysaccharide (EPS) and biogenic amine (BA) production. Shaded boxes indicate the presence of an attribute. Type strains of the species Strep. thermophilus were included for comparison. 


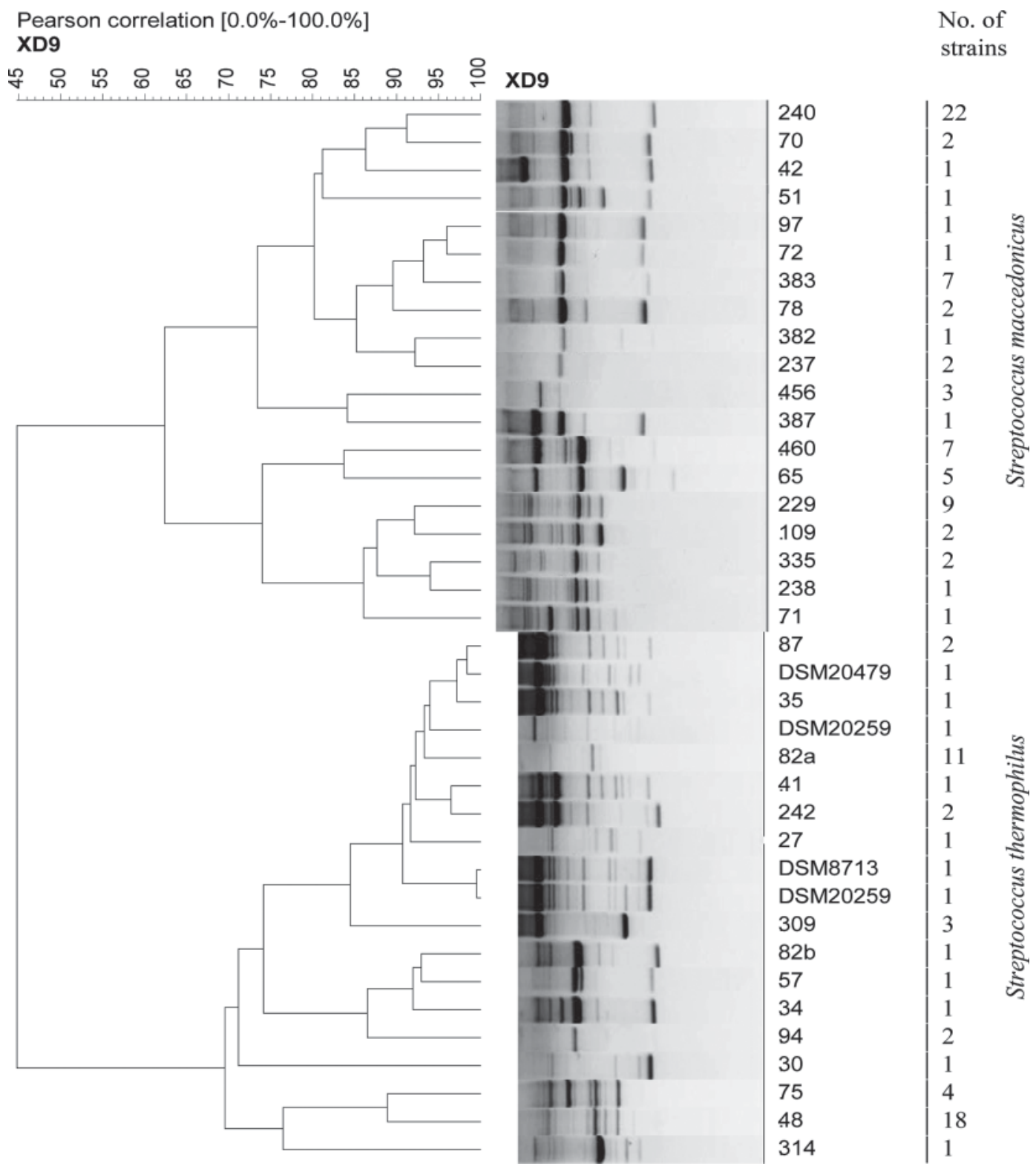

Figure 3. Dendrogram obtained from XD9 random amplification of polymorphic DNA (RAPD)-PCR fingerprints of 125 Streptococcus strains. Patterns were grouped with the unweighted pair group algorithm with arithmetic averages (UPGMA). Type strains of the species Strep. thermophilus were included for comparison.

tion after $6 \mathrm{~h}$ (Figure 1). Despite the higher number of strains with good or fair acidifying ability, the percentage of strains able to express proteolytic activity was less than $39 \%$ (Figure 2).

About $50 \%$ of Strep. macedonicus strains showed lipolytic activity toward tributyrin (Figure 2), confirming the hypothesis that Strep. macedonicus could have a greater effect on lipolysis than on proteolysis during cheese ripening (De Vuyst and Tsakalidou, 2008). Lipolysis was widespread even among Strep. thermophilus strains (34 strains out of 50), proving that thermophilic streptococci possess a high esterasic activity among lactic acid bacteria. All Strep. macedonicus strains were able to produce acid from galactose (Figure 2), as was reported in the first description of the species provided by Manachini et al. (2002). Surprisingly, only 4 strains of Strep. thermophilus proved unable to ferment this sugar (Figure 2). According to the literature, Strep. thermophilus is not capable of metabolizing galactose and thus expels this sugar into the medium during lactose fermentation (Mora et al., 2002; de Vin et al., 2005; Vaillancourt et al., 2008). In fact, galactose-fermenting 
Strep. thermophilus strains have been reported (Giraffa et al., 2001; Mora et al., 2002), but the high occurrence of galactose-fermenting strains recorded in this survey has never been reported before.

Based on the obtained results, tyrosine was the most decarboxylated amino acid by 17 out of 50 Strep. thermophilus, and 13 out of 71 Strep. macedonicus strains (Figure 2). In Strep. thermophilus species, in addition to tyrosine-decarboxylation, the first evidence was found in a limited number of strains with activity on ornithine and histidine. Previous studies investigating the production of biogenic amines by this species showed no activity or only tyrosine-decarboxylating activity (Straub et al., 1995; Bukková et al., 2009). Similar results were reported by Marino et al. (2008) in Strep. thermophilus strains isolated from Montasio cheese. None of the Strep. macedonicus strains could decarboxylize ornithine, and only 1 of 71 produced histamine. The percentage of strains able to decarboxylize tyramine (about 18\%) was higher than that recorded during a previous survey on this species (Georgalaki et al., 2000). No strain was able to utilize citrate (data not shown). This finding was not surprising for Strep. thermophilus because this species does not possess genes for citrate, malate, or gluconate transport and utilization (Hols et al., 2005). Conversely, according to Georgalaki et al. (2000), some Strep. macedonicus strains should grow on Simmons citrate agar with citrate as the sole carbon source. This trait in particular, together with fat and casein hydrolysis, would indicate the usefulness of this species as an adjunct or coculture (De Vuyst and Tsakalidou, 2008). With reference to EPS production, Strep. macedonicus strains exhibited a reduced variability, with more than $50 \%$ of the strains unable to produce EPS independently from the carbon source (Figure 2). In fact, Georgalaki et al. (2000) and Lombardi et al. (2004) did not find any EPS-producing strains during their surveys; and this capability was exclusively observed in one strain coming from the Nestlé Culture Collection (Vincent et al., 2001). In Strep. thermophilus, just 6 strains did not produce EPS under any conditions, and $64 \%$ of the strains were positive for EPS production in every medium (Figure 2). Moreover, the high variability in the patterns of sugar utilization could represent a further approach for strain characterization. Biochemical results allowed 49 different patterns to be detected: 33 out of 50 for Strep. thermophilus and 16 out of 71 for Strep. macedonicus. These characteristic profiles were used to construct a dendrogram on the Jaccard coefficient matrix via a modified UPGMA cluster analysis (Figure 2).

To evaluate if the detected phenotypic variability was reflected at the genetic level, a multilocus typing approach was carried out by analyzing all Streptococcus spp. strains by RAPD-PCR analysis. In preliminary RAPD experiments, primers XD5 (5'-CTGGCGGCTG-3'), OPI-02MOD (5'-GCTCGGAGGAGAGG-3'), REP-1 (5'-IIIICGICGICATCIGGC-3'), REP-2 (5'-ICGICTTATCIGGCCTAC3'), and XD9 were tested for their discrimination ability on a limited number of strains (data not shown). Primer XD9 was chosen because it gave the most reproducible band patterns and the higher strain differentiation, yielding 15 different RAPD profiles out of 50 strains in Strep. thermophilus, and 19 out of 71 strains in Strep. macedonicus (Figure 3). In other words, a remarkable genotypic heterogeneity between strains was highlighted in both species, confirming previous results obtained within Strep. thermophilus (Moschetti et al., 1998; Giraffa et al., 2001; Mora et al., 2002) and Strep. macedonicus species (Lombardi et al., 2004; Franciosi et al., 2009). Moreover, at a similarity level of $78 \%$, all the isolates and reference strains of Strep. thermophilus were grouped together and were well separated from the strains of Strep. macedonicus, confirming that these 2 species are different microbial entities, as previously indicated by both taxonomic and genotypic studies (Tsakalidou et al., 1998; Andrighetto et al., 2002).

\section{REFERENCES}

Andrighetto, C., F. Borney, A. Barmaz, B. Stefanon, and A. Lombardi. 2002. Genetic diversity of Streptococcus thermophilus strains isolated from Italian traditional cheeses. Int. Dairy J. 12:141-144.

Aponte, M., V. Fusco, R. Andolfi, and S. Coppola. 2008. Lactic acid bacteria occurring during manufacture and ripening of Provolone del Monaco cheese: Detection by different analytical approaches. Int. Dairy J. 18:403-413.

Baruzzi, F., A. Matarante, M. Morea, and P. S. Cocconcelli. 2002. Microbial community dynamics during the Scamorza Altamurana cheese natural fermentation. J. Dairy Sci. 85:1390-1397.

Bukková, L., F. Bukka, M. Hlobilová, Z. Vakátková, D. Nováková, and V. Dráb. 2009. Tyramine production of technological important strains of Lactobacillus, Lactococcus and Streptococcus. Eur. Food Res. Technol. 229:533-538.

Callon, C., L. Millet, and M. C. Montel. 2004. Diversity of lactic acid bacteria isolated from AOC Salers cheese. J. Dairy Res. 71:231244.

de Vin, F., P. Radstrom, L. Herman, and L. De Vuyst. 2005. Molecular and biochemical analysis of the galactose phenotype of dairy Streptococcus thermophilus strains reveals four different fermentation profiles. Appl. Environ. Microbiol. 71:3659-3667.

De Vuyst, L., and E. Tsakalidou. 2008. Streptococcus macedonicus, a multi-functional and promising species for dairy fermentations. Int. Dairy J. 18:476-485.

Díaz-Ruiz, G., J. P. Guyot, F. Ruiz-Teran, J. Morlon-Guyot, and C. Wacher. 2003. Microbial and physiological characterization of weakly amylolytic but fast-growing lactic acid bacteria: A functional role in supporting microbial diversity in Pozol, a Mexican fermented maize beverage. Appl. Environ. Microbiol. 69:43674374 .

Franciosi, E., L. Settanni, A. Cavazza, and E. Poznanski. 2009. Biodiversity and technological potential of wild lactic acid bacteria from raw cows' milk. Int. Dairy J. 19:3-11.

Gancel, F., and G. Novel. 1994. Exopolysaccharide production by Streptococcus salivarius spp. Thermophilus cultures. 1. Conditions of production. J. Dairy Sci. 77:685-688. 
Georgalaki, M., E. Manolopoulou, R. Anastasiou, M. Papadelli, and E. Tsakalidou. 2009. Detection of Streptococcus macedonicus in Greek cheeses. Int. Dairy J. 19:96-99.

Georgalaki, M. D., P. Sarantinopoulos, E. S. Ferreira, L. De Vuyst, G. Kalantzopoulos, and E. Tsakalidou. 2000. Biochemical properties of Streptococcus macedonicus strains isolated from Greek Kasseri cheese. J. Appl. Microbiol. 88:817-825.

Giraffa, G., A. Paris, L. Valcavi, M. Gatti, and E. Neviani. 2001. Genotypic and phenotypic heterogeneity of Streptococcus thermophilus strains isolated from dairy products. J. Appl. Microbiol. 91:937-943.

Hols, P., F. Hancy, L. Fontaine, B. Grossiord, D. Prozzi, N. LeblondBourget, B. Decaris, A. Bolotin, C. Delorme, S. Dusko Ehrlich, E. Guedon, V. Monnet, P. Renault, and M. Kleerebezem. 2005. New insights in the molecular biology and physiology of Streptococcus thermophilus revealed by comparative genomics. FEMS Microbiol. Rev. 29:435-463.

Isolini, D., M. Grand, and H. Glättli. 1990. Selektivmedien zum Nachweis von obligat und fakultativ heterofermentativen Laktobazillen. Schweiz. Milchwirtsch. Forsch. 19:57-59.

Joosten, H. M. L. J., and M. D. Northolt. 1989. Detection, growth, and amine-producing capacity of lactobacilli in cheese. Appl. Environ. Microbiol. 55:2356-2359.

Lanyi, B. 1987. Classical and rapid identification: Methods for medically important bacteria. Pages 1-67 in Methods in Microbiology. Vol. 19. R. R. Colwell, and R. Grigorova, ed. Academic Press, New York, NY.

Lombardi, A., M. Gatti, L. Rizzotti, S. Torriani, C. Andrighetto, and G. Giraffa. 2004. Characterization of Streptococcus macedonicus strains isolated from artisanal Italian raw milk cheeses. Int. Dairy J. $14: 967-976$

Manachini, P. L., S. H. Flint, L. J. H. Ward, W. Kelly, M. G. Fortina, C. Parini, and D. Mora. 2002. Comparison between Streptococcus macedonicus and Streptococcus waius strains and reclassification of Streptococcus waius (Flint et al., 1999) as Streptococcus macedonicus (Tsakalidou et al., 1998). Int. J. Syst. Evol. Microbiol. 52:945-951.

Marino, M., M. Maifreni, I. Bartolomeoli, and G. Rondinini. 2008 Evaluation of amino acid-decarboxylative microbiota throughout the ripening of an Italian PDO cheese produced using different manufacturing practices. J. Appl. Microbiol. 105:540-549.

Mora, D., M. G. Fortina, C. Parini, G. Ricci, M. Gatti, G. Giraffa, and P. L. Manachini. 2002. Genetic diversity and technological properties of Streptococcus thermophilus strains isolated from dairy products. J. Appl. Microbiol. 93:278-287.

Moschetti, G., G. Blaiotta, M. Aponte, P. Catzeddu, F. Villani, P. Deiana, and S. Coppola. 1998. Random amplified polymorphic DNA and amplified ribosomal DNA spacer polymorphism: Powerful methods to differentiate Streptococcus thermophilus strains. J. Appl. Microbiol. 85:25-36.

Pacini, F., D. Cariolato, C. Andrighetto, and A. Lombardi. 2006. Occurrence of Streptococcus macedonicus in Italian cheeses. FEMS Microbiol. Lett. 261:69-73.

Poyart, C., G. Quesne, and P. Trieu-Cuot. 2002. Taxonomic dissection of the Streptococcus bovis group by analysis of manganese dependent superoxide dismutase gene ( $\operatorname{sodA}$ ) sequences: reclassification of 'Streptococcus infantarius ssp. coli' as Streptococcus lutetiensis sp. nov. and of Streptococcus bovis biotype II.2 as Streptococcus pasteurianus sp. nov. Int. J. Syst. Evol. Microbiol. 52:1247-1255.

Poznanski, E., A. Cavazza, F. Cappa, and P. S. Cocconcelli. 2004. Indigenous raw milk microbiota influences the bacterial development in traditional cheese from an alpine natural park. Int. J. Food Microbiol. 92:141-151.

Straub, B. W., M. Kicherer, S. M. Schilchert, and W. P. Hammes. 1995. The formation of biogenic amines by fermentation organisms. Z. Lebensm. Unters. Forsch. 201:79-82.

Tsakalidou, E., E. Zoidou, B. Pot, L. Wassill, W. Ludwig, L. A. Devriese, G. Kalantzopoulos, K. H. Schleifer, and K. Kersters. 1998 Identification of streptococci from Greek Kasseri cheese and description of Streptococcus macedonicus sp. nov. Int. J. Syst. Bacteriol. 48:519-527.

Vaillancourt, K., N. Bedard, C. Bart, M. T. G. Robitaille, N. Turgeon, M. Frenette, S. Moineau, and C. Vadeboncoeur. 2008. Role of galK and galM in galactose metabolism by Streptococcus thermophilus. Appl. Environ. Microbiol. 74:1264-1267.

Vincent, S. J. F., E. J. Faber, J. R. Neeser, F. Stingele, and J. P. Kamerling. 2001. Structure and properties of the exopolysaccharide produced by Streptococcus macedonicus. Glycobiology 11:131-139.

Zoumpopoulou, G., B. Foligne, K. Christodoulou, C. Grangette, B. Pot, and E. Tsakalidou. 2008. Lactobacillus fermentum ACA-DC 179 displays probiotic potential in vitro and protects against trinitrobenzene sulfonic acid (TNBS)-induced colitis and Salmonella infection in murine models. Int. J. Food Microbiol. 121:18-26. 